\title{
TRADITIONAL USES OF BEGONIA SPECIES \\ (BEGONIACAE) IN NEPAL
}

\author{
S. Rajbhandary
}

\section{ABSTRACT}

In Nepal Begonia L. is represented by 22 species of which ten species are reported in having ethnobotanical value. The 22 Begonia species including the seven endemic species largely belong to 2 sections, Begonia sect. Diploclinium and Begonia sect. Platycentrum. Most Begonia species occur in eastern and central region, and few species in western region. In this paper, ten species of Begonia mostly used as food, ornamental purpose and for medicine in most parts of Nepal is described. Except for Begonia picta, the ethnobotanical uses of other Nepalese Begonia species have not been reported in any previous literature from Nepal.

Key words: Begonia, Impatiens, Makarkanchi, pickle, uses

\section{INTRODUCTION}

Begonias are of great horticultural interest, and they have long been in common use as ornamentals throughout the world. This has led to much botanical and horticultural investigation, and has resulted in many useful publications. According to Burkill (1935) leaves of Begonia are also used as a flavoring for mixtures of fish and meat. Begonias have been cooked up as potherbs in Japan, India, Indonesia and Myanmar (Burma). In Indonesia Begonia species like B. baliensis, B. lempuyangensis and B. multibracteata, with a robust habit and big stems are eaten in salads or cooked with fish. $B$. lempuyangensis is used as a palliative medicine for coughs. Similarly, B. lombokensis and B. longifolia are also eaten and/or used medicinally (Girmansyah 2009). They are also used as salads in China and Brazil. In Java, the Philippines and Brazil they are also a flavoring ingredients. In northern Mexico and China they are a favorite wild snack for children. In fact, some rural people use the tart sap to curdle milk for cheese making. In Paraguay, the leaves of the $B$. cucullata are eaten fried or in soup or salads while the sap is used to treat sore throats (Jordan 2008).

In the West Indies Begonia leaves are used as a tea for colds. Roots and tubers of Begonia species have been used as emetics and purgatives. The sap has been put on wounds, and concoctions used for cough, consumption, and fever. Shoots have been used to treat upset stomachs and enlarged spleens. The acid-based sap has been used to treat toothaches and gum aliments as it is considered anti-bacterial. It is also proven to have anti-tumor activity and commonly used in the West Indies by herbalists to treat cancer (Jordon 2008). Additionally, there are various reports from several countries from Mexico to India where Begonia species have been used for medicine, vitamin $\mathrm{C}$ and in some instances as a source of food (Jain and Dam 1979, Lauferriere 1990, Gaur 1999, Basurto-Pe et al. 2003, Lans 2006, Murugkarm 2006, Sajem and Gosai 2006). Wherever they grow they have been important to people. 
In Nepal horticultural interest has yet to flourish, but there are a few exotic species which are used as ornamental. In most part of Nepal, a few species of Begonia are use in different forms of food and in medicine, but so far this has not been comprehensively documented. The use of Begonia picta (local Nepali name 'Makarkanchi') as food was mentioned by Smith (1805) in "Exotic Botany", while describing plants from Nepal. Hooker (1855) also reported the stalks of great yellow-flowered Begonia ( $B$. flaviflora $\mathrm{H}$. Hara) being used to make sauce (as we do apple-sauce) for pork and the taste is mentioned as acid and very pleasant. Similarly, while describing Begonia cathcartii from Sikkim, Hooker (1855) also explained its use for food in "Illustration of Himalayan plants". Hooker wrote that the stem are eaten cooked, being pleasantly acid and they are mainly made into sauce for pork and other greasy meats by the native inhabitants of Sikkim.

However, except for Begonia picta little is known on the Nepalese uses of Begonia. The present study concentrates on traditional uses of Begonia species in Nepal, other than for ornamental purposes, seeking to improve the knowledge of traditional uses of Begonias in Nepal, before this knowledge is lost.

\section{MATERIALS AND METHODS}

The study on the use pattern of Begonia species in Nepal is based on the field survey and interviews with locals and local practitioners as well as supplemented by relevant secondary information (articles, reports, books, etc). Several field visits were undertaken between 20052008 in eastern (Tehrathum, Panchthar and llam districts), central (Dolakha, Kaski, Rasuwa, Kathmandu, Makwanpur, Nawalparasi Gulmi, Palpa Parbat, Baglung, Arghakhanchi and Tanahu districts), and western (Pyuthan district) Nepal (fig. 1). During the collection of Begonia species in various parts of Nepal, information on its uses, consumption and mode of preparation were obtained from the local people of the study area. Information was obtained by directly interviewing housewives, shepherds, local healers and people on the trail. The information was further verified by crosschecking and validating by the common response from different locals. Semi-standard questionnaire was used and the key informants were randomly selected.

Collections of herbarium samples were completed from the plant's growing sites as well as from the villages near the collection sites. Herbarium specimens were prepared by using a standard herbarium technique (Martin 1995). The plant specimens were identified by using standard literatures (Hooker 1872, Hara and Williams 1979, Smith 1805, Polunin and Stainton 1984, Grierson 1991) and also by comparing with the authentically identified specimens deposited at Tribhuvan University Central Herbarium (TUCH), Central Department of Botany, Kirtipur, National Herbarium and Plant Laboratories (KATH), Godavari, Kathmandu, Natural History Museum, London (BM), Royal Botanic Garden, Edinburgh (E) and Royal Botanic Gardens, Kew (K). Vouchers specimens are deposited at the Tribhuvan University Central Herbarium (TUCH).

\section{RESULTS AND DISCUSSION}

In Nepal most Begonia species occur in eastern and central region, with few species in western region. In addition to the high ornamental value, the genus Begonia in Nepal is used both medicinally and for food. During the field work in most part of the eastern and central Nepal, the succulent leaf stalks or the stems of almost all the species are peeled and eaten raw as 
salad, as well as cooked for its delicious sour taste. Raw and boiled petioles and stems of several species of Begonia are consumed as a pickle by the local people in most parts of Nepal. These are widely used by the locals mainly during the monsoon season when there are extensive quantities of Begonia growing in several places. Most of the species are used as medicine to cure toe wounds during monsoon usually caused by standing all day in mud when planting rice in paddy fields. The ten species are mostly used as food, some are planted for ornamental purpose and five species are used as medicines in most parts of Nepal are briefly described below with their short description.

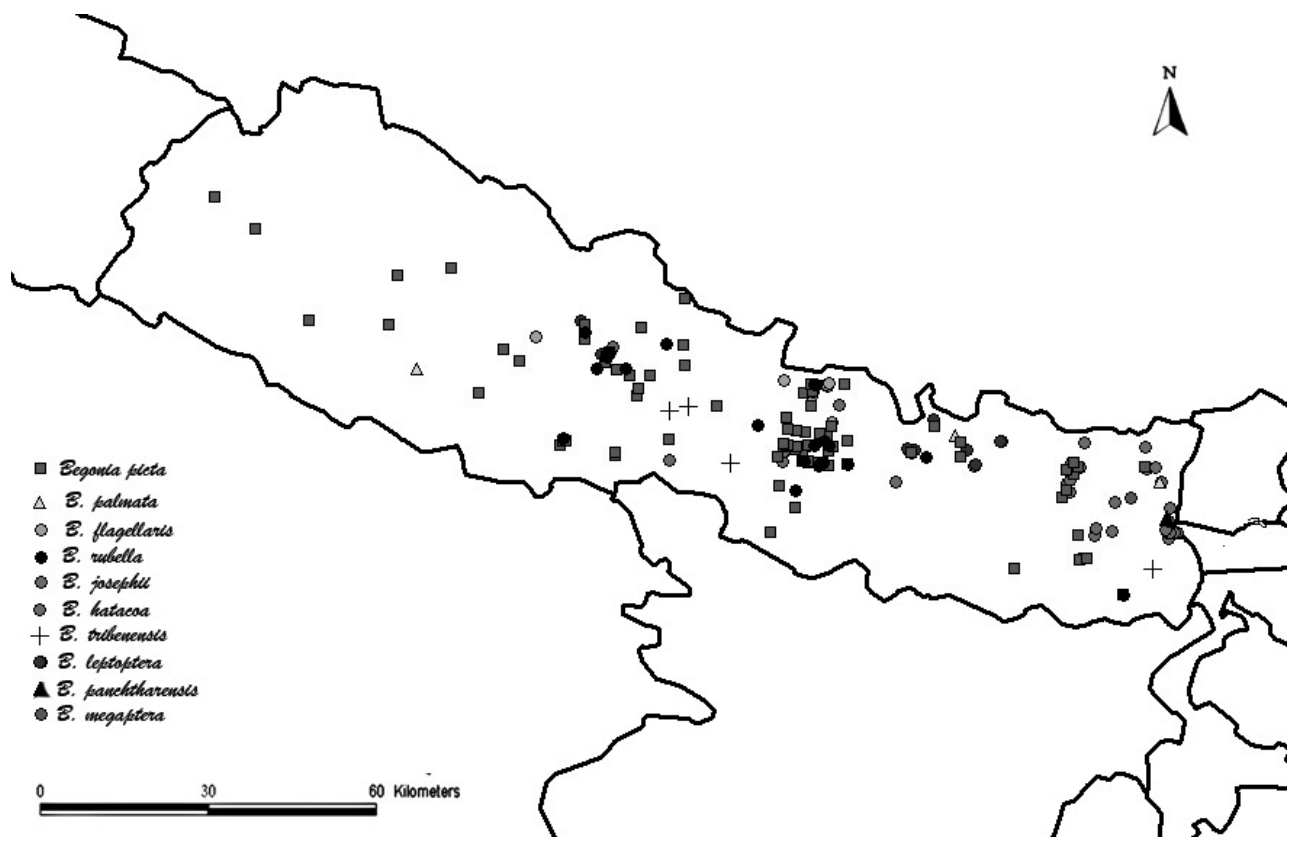

Figure 1. Map of Nepal showing the sampling sites.

1. Begonia flagellaris Hara (fig. 2a) have long creeping red succulent leafy stolons and bears ascending inflorescences, with pink or white flowers at their lower nodes. It is an endemic species of Nepal, growing between 2200-2700 m.

Due to its succulent petioles and sour taste the petioles and the stems are eaten raw by children and locals in the forest while herding cattle or while walking on the hills in Charikot, Dolakha district. The Gurungs of Chomrung and Sinwa in Kaski district and Tamang community in different parts of Rasuwa district (central Nepal) use the petioles mixed with the petioles of Begonia flagellaris and Begonia picta as pickle with a very very sour taste. 


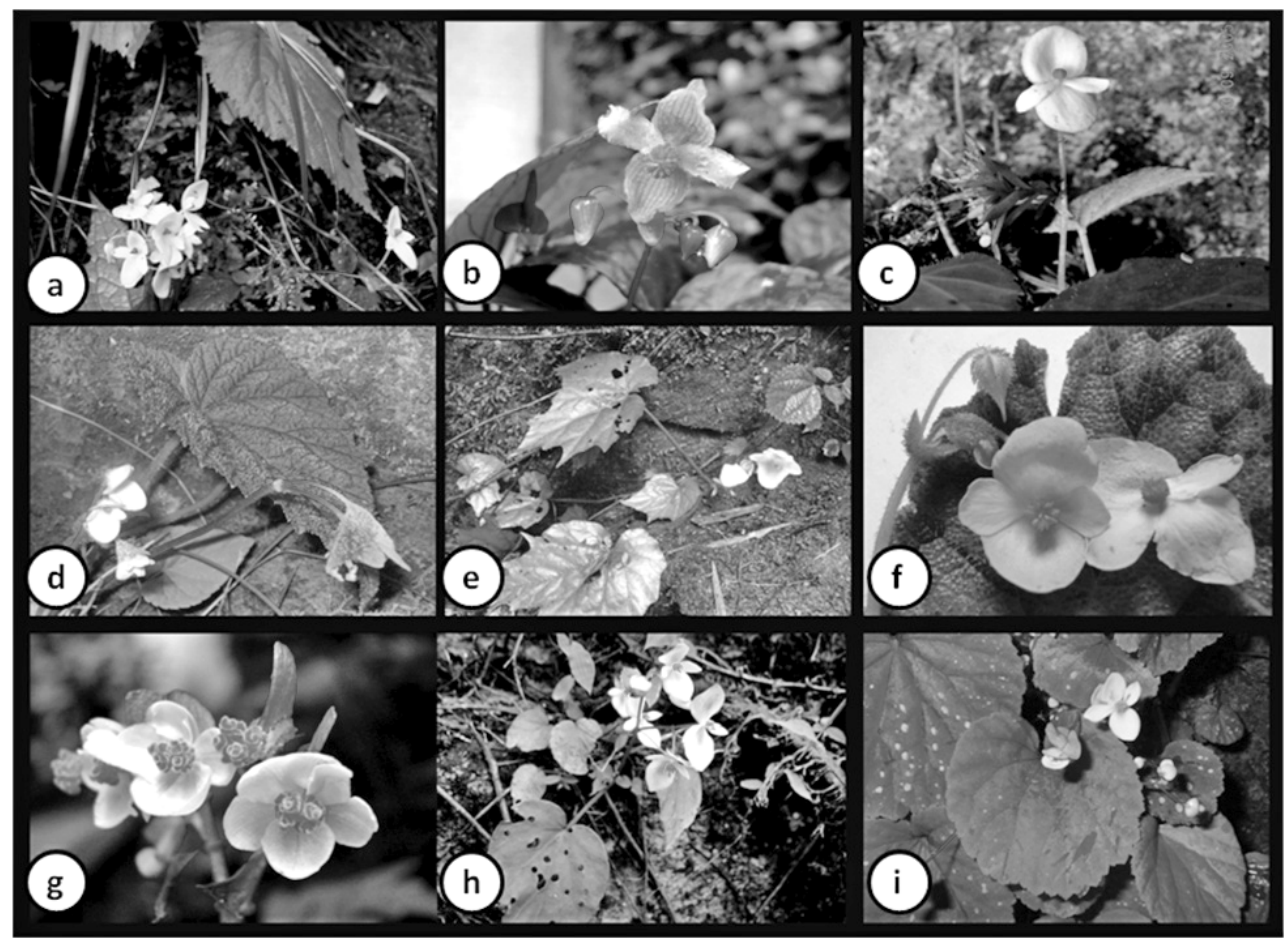

Figure 2. (a) Begonia flagellaris; (b) B. hatacoa; (c) B. josephii; (d) B. leptoptera; (e) B. palmata; (f) B. picta; (g) B. panchtharensis; (h) B. rubella; (i) B. tribenensis.

2. Begonia hatacoa Buch.-Ham ex D. Don (fig. $2 b$ ) is a perennial herb with cauline alternate leaves having densely brown hirsute petioles and flowers with pink stripes on the outer tepals. It is found in central and eastern part of Nepal distributed between 1200-2500 m.

Juice of the rhizome is used to kill intestinal worms or used as anthelmintic in Pharping, Kathmandu district (central Nepal) by Newar community. Balami (2003) reported similar use, but wrongly attributes this to as Begonia nepalensis (A. DC.) Warburg.

3. Begonia josephii A. DC. (fig. 2c) a perennial acaulescent herb with globose tuber and peltate leaves, mostly with white or pink flowers, is distributed in central and eastern Nepal between 1000-2700 m altitudes.

Tender shoots and petiole are eaten raw or fermented as pickle in most part of the Dolakha district (central Nepal) by Brahmin, Chettries, and Newars, which has also been reported by Shrestha and Dhillion (2003). In Maimajuwa llam district (eastern Nepal), Begonia josephii is found dominant between $1800-2200 \mathrm{~m}$. This species is surprisingly not in use, but there is a local saying that if the plant is collected and brought down near a paddy field, the paddy dies out before it matures, therefore: a very bad sign. However, this species is eaten raw in Charikot 
area in Dolakha district (central Nepal).

4. Begonia leptoptera Hara (fig. 2d) another endemic species of Nepal, found between $1500-2600 \mathrm{~m}$, is an erect plant with tubers, long petioled, radicle leaves, and pink flowers. The species is very similar with $B$. josephii but differs in having non-peltate maculate leaves, simple umbellate inflorescences and lanceolate narrow ascending wing capsule.

The red petioles are eaten raw or as pickle in Dolakha by Tamangs, Sherpas, Brahmins, Chettries, and Newars, and by Gurungs in Kaski district (central Nepal).

5. Begonia megaptera A. DC. distributed in central Nepal between $500-1500 \mathrm{~m}$, is an erect herb, with smooth green leaves having unequal base and white flowers.

The plant is locally known as 'Amilchari' in Daman, Makwanpur district (central Nepal), which means the plant having sour taste, and people eat raw petioles and stems. Similar, findings have been reported by Sigdel (Sigdel 2004) from Daman, Makwanpur district. The juice of the whole plant is used to kill intestinal worms and cure toe wounds in Daman, Makwanpur district (Sigdel 2004), and in Rasuwa district (Shrestha 2008).

6. Begonia palmata D. Don (fig. 2e) distributed in central and eastern Nepal between 1500$2400 \mathrm{~m}$, is an erect herb, with shallowly denticulate, to distinctly divided lobed large leaf which are densely and white flowers.

The plant is locally known as 'Thulo Magar Kanche' and are used as ornaments in Godawari and Daman area. This finding is similar to that of Malla and Kurmi (2004) who have also reported the ornamental used from Phulchoki and Godawari, from Daman by Pathak and Pandey (2005) and by Shrestha (2008) from Rasuwa district.

7. Begonia picta Sm. (fig. 2f) is widely distributed in Nepal from the west to the eastern part of the country from the lowlands to the lower temperate region between $150-2800 \mathrm{~m}$, normally known as 'Makarkachi'. This perennial herb with globose rhizome, variegated leaves, light or dark pink flowers, flowers from July to September.

It is still popularly used in many parts of Nepal as an ornamental pot plant, and is used for the treatment of mud induced toe wounds. Tender shoots are fermented and eaten as pickles. Similar results have also been reported by Gurung (2006) and Shrestha (1987) that B. picta being eaten raw or as pickle in Sikles by Gurungs and adjoining areas of Pokhara. The leaves have an acidic taste and are eaten raw as well as cooked for its delicious, sour taste in Palpa. This result is also supported by similar findings of the species being consumed as 'Chatni (kind of pickle)' by the local people in Daman and Dolakha (Pathak and Pandey 2005, Shrestha and Dhillion 2006), and pickled petiole as appetizer in Karnali zone (Bhattarai 1992). The flower is also used for making pickles around Daman area, Makwanpur district (Sigdel 2004).

In most of the areas in the mid-land of central and eastern Nepal, the juice of the whole plant of B. picta is used as leech guard by local tribes. Sigdel (2004), Pathak and Pandey (2005) have also reported the use of flower juice/paste as leech guard around Daman area.

Leaf juice of Begonia picta, locally known as 'Prakyung' by Tamang, is used for the treatment of toe wounds in Rasuwa district as well as in other districts like Kavrepalanchok, Dolakha, 
Dhading, Pyuthan, Gulmi, Baglung, Parbat, Tanahu. This result is supported by similiar findings of Pathak and Pandey (2005) from Makwanpur and of Thapa (2008) from Nawalparasi.

Root infusion of $B$. picta is taken orally in Sikles area of Kaski district to cure constipation, also reported by Gurung (2006). Paste of young shoot is applied in cuts and wounds, and also taken for respiratory tract infections and during headache in Dolakha district. These findings are similar to those reported by Shrestha and Dhillion (2003) from Dolakha, while Manandhar (1994 2000) reported it from Kaski district with additional information where leaves are crushed and applied to sore nipples following child birth (Manandhar 2000).

In Gulmi, Parbat, Baglung, Pyuthan districts (western Nepal), it has been found that people use mature root stalks and petioles of $B$. picta for preparing red dyes for painting hands and feet by mixing its juice with the crushed leaves of Impatiens spp. especially in the month of July/ August to mark the especial festival 'Srawane Sankranti', which is celebrated all over Nepal. Painting hands and feet during the festival is a tradition, which used to occur only in western Nepal, but now with migration this is practiced throughout Nepal. Thapa (2008) has also reported the use of $B$. picta in paintings of hands during 'Srawane Sankranti' by Brahmans, Chettri and Newar women in Nawalparasi district and from Arghakhanchi district (Panthi 2007). Matured root stalks of all varieties of Begonia are used for preparing red dyes by mixing its juice with the crushed leaves of Impatiens sp. is also used by the Nagas in Nagaland (Changkija 1999).

8. Begonia panchtharensis S. Rajbhandary (fig. $2 \mathrm{~g}$ ) is a perennial herb with elongated thick rhizome, basal, large and almost glabrous leaves, six tepaled female flowers and is distributed in eastern Nepal, growing on shady river banks and edge of the forest near rivers at. 2200-2300 m.

In Memeng, Panchthar district (eastern Nepal), this plant is found to feed pigs and the decoction of the rhizome is given for stomach-aches mostly by Limbu and Rai ethnic groups.

9. Begonia rubella Buch.-Ham. ex D. Don (fig. $2 \mathrm{~h}$ ) a perennial erect herb with green succulent petiole and globose elongated orange coloured tubers, with pink flowers are important Begonia species in having various uses. They are mostly found growing under moist shady sloped forest edges between elevations ranging from $600-1700 \mathrm{~m}$. It is locally known as 'Bhir amilo' where 'Bhir' means slopes and 'Amilo' means sour taste, on the whole it refers to a plant having sour text and growing on slopes.

Petioles are eaten raw in Palpa district, while a leaf paste is applied on cuts and toe wounds due to long period in mud especially during monsoon in many places of central Nepal like, Parbat, Arghakhanche, Gulmi, Palpa, Baglung, Tanahu district and Pyuthan of western Nepal. Shakya (1994) reported similar findings from Palpa district, and Shrestha (2008) from Rasuwa district. In Tehrathum district (eastern Nepal), leaves of $B$. rubella (Makarkachi) is taken for chest pains also reported by Rai (2003) for Rai, Limbu, Sherpa, Tamang, Magar, Gurung, and Newar ethnic communities. While, a paste of the whole plant is used externally by Tamangs to cure boils in Rasuwa district, which also supports the findings of Shrestha (2008).

The leaf paste of Begonia rubella mixed with the paste of Phyllanthus emblica is used by Magars to prepare a black hair dye in Palpa district is also reported by Shakya (1994). Black dye is also prepared from both Begonia rubella and Begonia picta in Rasuwa district by Ta- 


\section{mangs (Shrestha 2008).}

10. Begonia tribenensis Rao (fig. $2 \mathrm{i}$ ) another endemic species distributed in central and eastern Nepal, is mostly single-leaved tuberous herbs with long pinkish red petiole, and white flowers. It is found mostly in the tropical and subtropical region between the elevations of 150$600 \mathrm{~m}$. It is a rare species growing on rock-crevices and boulders in shady areas along the river banks and edges.

The petiole of Begonia tribenensis is also found to be eaten raw in Damauli, Tanahu district (central Nepal) as other species.

Beautiful flowers and attractive leaves of Begonia species as observed during this study suggest the horticultural potential of Begonia in Nepal. Begonia picta (Shobvhaparni), Begonia rubella (Bhir amilo), and Begonia palmata (fig. 2i) (Thulo Magar Kanche) have already been suggested as wild ornamental plants of Phulchoki and Godawari ( Malla and Kurmi 2004) and in Rasuwa district (Shrestha 2008) and in Daman (Pathak and Pandey 2005).

In the present study, ten species of Nepalese Begonia have been found as useful in the study area for different purposes especially for medicine, food and as ornamental plant. No proper documentation of the use of Begonia has been undertaken before, except for B. picta (Smith 1805). The use of endemic species Begonia flagellaris, $B$. leptoptera and $B$. tribenensis has been recorded here for the first time. The petioles of these three species are eaten raw or as pickles or salad by the local people. Begonia picta is found as the most common species in the study area in Nepal (Rajbhandary et al. 2010) having a wide range of distribution both vertically as well as horizontally and also has widest use as food, medicine, ornamentals and occasionally in the preparation of dye. In Memeng, Panchthar district (eastern Nepal) B. panchtharensis are fed to pigs and the decoction of the rhizome is taken in stomach pain which is a new finding.

According to the local informants, this knowledge has have been passed down from generation to generation in many parts of Nepal. One good example is the medicinal use for the treatment of toe wounds which is one of the quickest cures. Most of the people still live in the rural areas and are still engaged in subsistence farming. Toe wounds caused by standing long periods in paddy field during the rainy season are very common in most part of Nepal. This is the main season for rice planting and the people stay, in the paddy field almost the whole day planting rice seedlings. As Begonia is mostly found growing in this season, it has become the easiest and cheapest remedy for the farmers mostly in the hilly region to cure toe wound, which takes two to three days to be cured completely. Use of plant paste for the treatment of toe wounds could be suggested for further research in chemical analysis to find out the important component of the species that might lead to the findings of new drug for toe wounds as this is a cheapest and quickest remedy but seasonal.

From the study and collection of the plant specimens, it is recommended that all the endemic species as well as other species of Begonia, except $B$. picta, should be placed on a plant protection list before they become threatened or extinct. In most part of the rural areas of Nepal, roads are being constructed and this has resulted into habitat loss. Environmental changes are another factor leading to the demise of threatened species. The distribution and growth of most Begonias is greatly influenced by environment factors as most of the species are found in 
shady damp places in rock crevices or on moist tree trunk full of mosses. Destruction of habitat by soil erosion in the hills due to monsoon carries away boulders and logging activities that silt up rivers is a major threat as Begonias often grow on riverside boulders. Deforestation in most of the rural parts of Nepal for shifting agriculture is also destroying the habitats required for Begonias, so it should be conserved before it gets rare or extinct both by in situ conservation as well as ex situ plans by harnessing its horticultural value. Further research should be carried out on the uses of Begonia for the remaining species as well.

\section{ACKNOWLEDGEMENTS}

The author likes to thank all the local people for providing the valuable information during the field survey. The author sincerely thanks the curators of BM, E, K, KATH, MICH and TUCH for allowing access to herbarium material. And acknowledge the whole team of CEPF Project - Lower Kanchenjunga-Singalila Ridge, Eastern Nepal, and team of Plantlife International Project, Rasuwa, Central Nepal for their extensive help in the collection of the specimens. A special credit goes to the Critical Ecosystem Partnership Fund (CEPF) USA, WWF (Nepal) and University Grants Commission (UGC) Nepal, for partial support to carry out the field visit. Finally, special thanks goes to the students, friends and Shambu R. Bista, Plant collector, Central Department of Botany, Tribhuvan University, Kirtipur, Kathmandu for their help during the field trips.

\section{REFERENCES}

Balami, N.P., 2003. Ethno-ecology of medicinal and aromatic plants of Kharpa Community Forest. M.Sc. Dissertation, Central Department of Botany, Tribhuvan University, Kirtipur, Kathmandu, Nepal.

Basurto-Pe, F., D. M. A. Castro-Lara, A. Martínez, 2003. Edible Begonias from the north of Puebla, Mexico. J. Econ. Bot., 57:48-53.

Bhattarai, N.K., 1992. Medical ethnobotany in the Karnali zone. Nepal. Economic Botany, 46(3):257-261.

Burkill, I.H., 1935. A Dictionary of the Economic Products of the Malay Peninsula. I (A-Cod). Governments of the Straits Settlements and Federated Malay States by the Crown Agents for the Colonies. London, 313-314.

Changkija, S., 1999. Folk medicinal plants of the Nagas in India. Asian Folklore Studies, 58:205-230.

Gaur, R.D., 1999. Flora of the District Garhwal North West Himalaya (with ethnobotanical notes). Trans Media Publication, India.

Girmansyah, D., 2009. A taxonomic study of Bali and Lombok Begonia (Begoniaceae). Reinwardtia, 12(5):419-434.

Grierson, A.J.C., 1991. Begoniaceae. In Grierson, A.J.C. and D.G. Long (eds) Flora of Bhutan. Vol. 2, Part 1. Royal Botanic Garden, Edinburgh (Begoniaceae: 237-246).

Gurung, L.J., 2006, Indigenous knowledge on non-timber forest products and socioeconomic 
importance of Nigalo and Allo in Sikles area of Kaski district, central Nepal. M.Sc. Dissertation, Central Department of Botany, Tribhuvan University, Kirtipur, Kathmandu, Nepal.

Hooker, J.D., 1855. Illustration of Himalayan Plants. PI. 13

Hooker, J.D., 1872. Flora of British India. L. Reeve and Co. Ltd. England, Vol. II:635-656.

Jain, S. and N. Dam, 1979. Some ethnobotanical notes from north-eastern India. J . Econ. Bot., 33:52-56.

Jordan, D., 2008. Waxing about edible Begonias. http://www.eattheweeds.com/ www.EatTheWeeds.Com/EatTheWeeds.com/Entries/1958/5/25_Begonias (Accessed on 22 October 2008).

Lans, C.A., 2006. Ethnomedicines used in Trinidad and Tobago for urinary problems and diabetes mellitus. Journal of Ethnobiology and Ethnomedicine, 2:45 Published online 2006 October 13. doi:10.1186/1746-4269-2-45.

Lauferriere, J., 1990. On the edibility of Begonias (J). The Begonian, 57(2):175.

Malla, K.J. and P.P. Kurmi, 2004. Wild ornamental plants of Phulchowki and Godawari. Bulletin of Department of Plant Resources, 25:22-37.

Manandhar, N.P., 1994. An ethnobotanical survey of herbal drugs of Kaski district. Nepal. Fitoterapia, 65(1):7-13.

Manandhar, N.P., 2000. Plants and People of Nepal. Timber Press, Portland, Oregan.

Martin, G.J., 1995. Ethnobotany: A Methods Manual. Chapman \& Hall, London.

Murugkarm, A.D., 2006. Interventions using wild edibles to improve the nutritional status of Khasi tribal women. Human Ecology Special Issue, 14:83-88.

Panthi, M., 2007. Plant diversity and resource utilization in central Himalaya: Arghakhanchi and Manang districts, Nepal. Ph. D. Thesis, Central Department of Botany, Tribhuvan University, Kirtipur, Kathmandu, Nepal.

Pathak, L. and S.R. Pandey, 2005. Ethno-medicinal plants of Daman area, central Nepal. Bulletin of Department of Plant Resources, 26:30-32.

Polunin, O. and A. Stainton, 1984. Flowers of the Himalaya. Oxford Press, New Delhi, India . Rai, M.B., 2003. Medicinal plants of Tehrathum district, eastern Nepal. Our Nature, 1:42-48. Rajbhandary, S., M. Hughes and K.K. Shrestha, 2010. Distribution patterns of Begonia species in the Nepal Himalaya. Botanica Orientalis-Journal of Plant Science, 7(1):73-78.

Sajem, A.L. and K. Gosai, 2006. Traditional use of medicinal plants by the Jaintia tribes in north Cachar Hills district of Assam, northeast India. Journal of Ethnobiology and Ethnomedicine, 2:33. Published online 2006 August 9. doi: 10.1186/1746-4269-2-33.

Shakya, R., 1994. Study on wild edible plants of Palpa district western Nepal. M.Sc. Dissertation, Central Department of Botany, Tribhuvan University, Kirtipur, Kathmandu, Nepal. 
Zone, central Nepal, with application of GIS and RS. Ph. D. Thesis, Central Department of Botany, Tribhuvan University, Kirtipur, Kathmandu, Nepal.

Shrestha, K., 1987. Report on edible wild plants from Pokhara and its northern region. J. Nat. Hist. Mus., 11:85-98.

Shrestha, P.M. and S.S. Dhillion, 2003. Medicinal plant diversity and use in the highlands of Dolakha district. Nepal. Journal of Ethnopharmacology, 86:81-96

Shrestha, P.M. and S.S. Dhillion, 2006. Diversity and traditional knowledge concerning wild food species in a locally managed forest in Nepal. Agroforestry Systems, 66:55-63.

Sigdel, K.P., 2004. NTFPs of two community forest of Makawanpur district: availability, utility and sustainability. M.Sc. Dissertation, Central Department of Botany, Tribhuvan University, Kirtipur, Kathmandu, Nepal.Smith, J.E., 1805. Exotic Botany, 2:81-82 t101.

Thapa, K.P., 2008. Comparative use pattern of medicinal plant species among eight ethnic/ caste groups of Benimanipur VDC, Nawalparasi District. M.Sc. Dissertation, Central Department of Botany, Tribhuvan University, Kirtipur, Kathmandu, Nepal.

\section{AUTHOR'S ADDRESS}

Sangeeta Rajbhandary

Central Department of Botany

Tribhuvan University, Kirtipur, Kathmandu, Nepal

(email: imogine3@gmail.com) 